\title{
The Mangroves of the East of Madagascar: Ecological Potentials and Pressures
}

\author{
Andriamparany Rakotomavo \\ Higher Institute of Sciences, Environment and Sustainable Development-ISSEDD Mangrove Team, University of Toamasina, \\ Toamasina, Madagascar \\ Email: andri.savaivo@blueline.mg
}

How to cite this paper: Rakotomavo, A. (2018) The Mangroves of the East of Madagascar: Ecological Potentials and Pressures. Open Journal of Ecology, 8, 447-458. https://doi.org/10.4236/oje.2018.88027

Received: July 13, 2018

Accepted: August 27, 2018

Published: August 30, 2018

Copyright (c) 2018 by author and Scientific Research Publishing Inc. This work is licensed under the Creative Commons Attribution International License (CC BY 4.0).

http://creativecommons.org/licenses/by/4.0/

\begin{abstract}
With 213,000 ha of remaining mangroves in 2016, Madagascar has about 4260 ha of mangrove on its Eastern coast. The purpose of this article is to provide essential data on the spatial distribution of this ecosystem of Eastern Madagascar, its ecological potentials and the pressures on its resources. Five Eastern Mangrove sites were selected, from South to North, because of their accessibility and their spatial position: Foulpointe, Sainte Marie, Manompana, Mananara Nord and Rigny. Eastern mangroves regenerate quite well, with a regeneration rate of over $500 \%$. Their height and basal area range respectively between $1.7-12 \mathrm{~m}$ and $7-42 \mathrm{~m}^{2} \cdot \mathrm{ha}^{-1}$. The aboveground biomass perfacies can go up to $47 \mathrm{t} \cdot \mathrm{ha}^{-1}$, or even more, at the level of the large homogeneous mangrove of Mananara and Rigny $\left(>70 \mathrm{t} \cdot \mathrm{ha}^{-1}\right)$, whereas this one does not exceed $10-20 \mathrm{t} \cdot \mathrm{ha}^{-1}$ in the sporadic mangroves of Foulpointe and Manompana. The carbon sequestration capacity of the aboveground biomass is estimated at more than 5 - 20 t.ha ${ }^{-1}$, along a South-North gradient, equivalent to a minimum sequestration potential of 21,300 to $85,200 \mathrm{t}$ for the whole East. Despite these ecological potentials and the low annual clearance rates observed for some sites, this ecosystem is subject to anthropogenic pressures linked to urbanization, timber harvesting and irrational exploitation of fishery resources.
\end{abstract}

\section{Keywords}

Malagasy Eastern Mangrove, Pressures, Ecological Potentials, Carbon, Biodiversity

\section{Introduction}

With 213,000 ha of remaining mangroves in 2016 [1], Madagascar has about 4260 ha of mangrove on its Eastern coast. Very little studied so far, this Eastern 
ecosystem remains unrecognized [2] despite the ecological, social and economic functions it provides [3]. However, the two recent articles of Rakotomavo et al. [4] [5] confirm not only how important the Malagasy Mangroves of eastern Madagascar are, but also the new knowledge on some Mangrove sites in the area. Described as small mangroves [6] for the most part, the mangroves of the Eastern Malagasy coast are generally located in bays where the wave strength is more attenuated [7]; that is to say, the low tide which is comprised between 0.5 to $1 \mathrm{~m}$ according to [8], as well as the difficulty of the hydro-dynamic sedimentation process described by [4] [5], do not favor the installation of mangroves along the East coast of the island.

Comprising a rich, varied and complex ecosystem [9], mangroves constitute an important ecological niche for the food and financial resources of the riparian population. As small as they are, they must be considered in the same way as other development factors. This article gives an inventory and a first description of this ecosystem of the East Malagasy coastline. Its purpose is to provide essential data on its spatial distribution, its ecological potential and the pressures it undergoes. It started from a hypothesis on the absence of pressure on this ecosystem, as well as on the floristic poverty of the latter.

\section{Materials and Methods}

Five main mangrove sites on the Eastern coast of Madagascar were chosen from South to North because of their accessibility and spatial position: Foulpointe, Sainte Marie, Manompana, Mananara Nord and Rigny (Figure 1). All these sites belong to the warm and humid climate area of eastern Madagascar. However, the value of their climatic parameters vary in terms of average annual temperatures and rainfall, respectively: $25^{\circ} \mathrm{C}$ and $1330 \mathrm{~mm}$ in Rigny Bay, $26^{\circ} \mathrm{C}$ and $2476 \mathrm{~mm}$ in Mananara Nord, $24^{\circ} \mathrm{C}$ and $3060 \mathrm{~mm}$ in Manompana, $25.5^{\circ} \mathrm{C}$ and $3369 \mathrm{~mm}$ in Sainte Marie, $22^{\circ} \mathrm{C}$ and $2986 \mathrm{~mm}$ in Foulpointe. With 110 to $280 \mathrm{~mm}$ of monthly rainfall, the five study sites have no dry season [2] [5] [10].

From June 2017 to September 2017, floristic and forest inventory work was carried out at these sites to know their floristic biodiversity, their forest potential in terms of aboveground biomass and regeneration capacity. Transects of 50 $100 \mathrm{~m}$, perpendicular to the coast line and/or water courses, including $10 \mathrm{~m} \times 10$ $m$ plots [11], were surveyed to assess abundance and the tree density of different development stages, as well as their dimensions in terms of diameter at breast height and heights (total and that of the bole). The regeneration potential of trees was assessed from the ratio between regenerated individuals and seed individuals. This potential is very low for a regeneration rate $\mathrm{T}<100 \%$; it is average for a value between $100 \%$ and $300 \%$. The potential is respectively good to very good for $300 \%<\mathrm{T}<1000 \%$ and $\mathrm{T}>1000 \%$ ([12] [13]).

35 - 55 trees per site were randomly selected, slashed to the ground and weighed on site using a precision scale at 0.001 . Samples of boles, aerial roots, leaves, flowers, seeds and branches were taken and brought back to the laboratory 


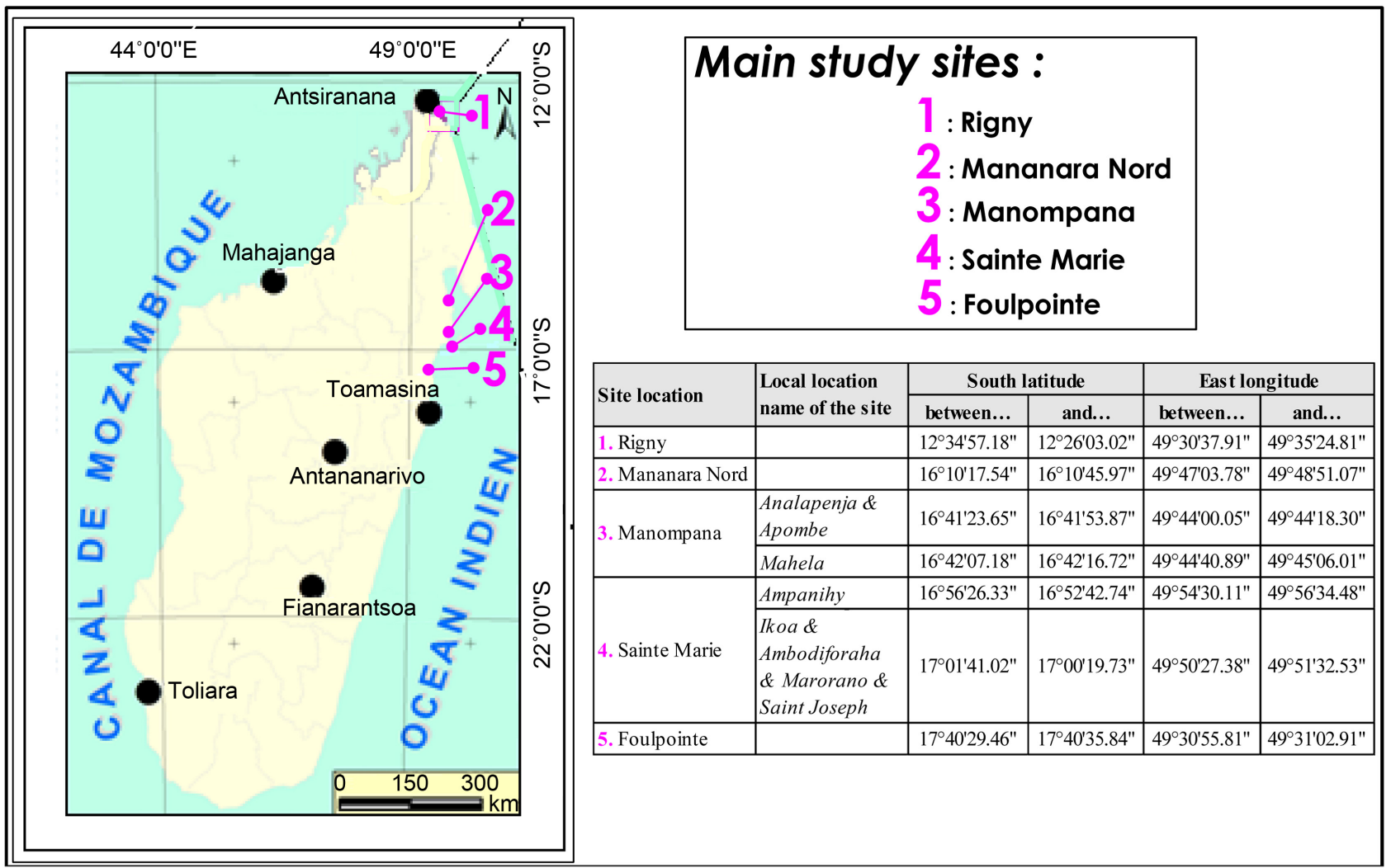

Figure 1. Location map and geographic coordinates of the main study sites.

for drying in an oven at $105^{\circ} \mathrm{C}$ for 48 hours. This operation allowed calculating the dry weight of tree samples taken from fields. Knowledge of the dry weight of the aboveground biomass $\mathrm{B}$ was used to calculate the carbon stock $\mathrm{C}$ content in their above-ground portion, according to the formula $\mathrm{C}=\mathrm{B} / 2$ [14].

The diachronic satellite image analysis Landsat 8 OLI and Google Earth 2016, combined with interviews of residents living on the mangrove lots, allowed to understand the magnitude of the anthropogenic pressures experienced by each site. From June 2017 to September 2017, 33 people living near mangrove sites were surveyed in Foulpointe, 158 in Sainte Marie, 33 in Manompana and 78 in Rigny. In other words, $10 \%$ to $17 \%$ of the residents and/or direct users of the mangrove lots studied were surveyed. It should be noted that the interviews had been focused on the qualitative and quantitative anthropogenic use of Mangrove resources.

\section{Results}

\subsection{Sporadic Mangrove Plots}

The spatial distribution of mangroves in Eastern Madagascar is sporadic, with the exception of the few homogeneous mangrove sites in the Sainte Marie, Mananara Nord and Manompana complex (Analanjirôfo Region, 371 ha) on one hand, and that of the Ambodivahibe, Rigny and Irodo complex (Diana Region, $\sim 3831 \mathrm{ha}$ ), on the other hand. The latter gathers nearly $90 \%$ of the mangroves of 
the East. That means, from South to North, from Fort Dauphin to Farafangana $(<100 \mathrm{ha})$, through Foulpointe ( $<2 \mathrm{ha})$ and Tampolo $(<0.5 \mathrm{ha})$, small lots of scattered and heterogeneous mangroves stretch along the littoral. Table 1 shows the estimated area of the main Eastern mangrove plots of Madagascar.

\subsection{Five to Eight Species of Mangrove Trees}

With 5 to 8 species, the floristic biodiversity of the whole of eastern Madagascar resembles that of the west coast. The 6 western typical families, namely Avicenniacea, Rizhophoraceae, Meliaceae, Combretaceae, Sonneratiaceae and Sterculeaceae are all present in the East. In Rigny bay, at least 6 species can be found, compared to 8 in Mananara Nord and Sainte Marie, 7 in Manompana and 5 in Foulpointe (Table 2).

\subsection{Medium to High Regeneration Potential in Places}

Globally, Eastern mangroves regenerate well, with a regeneration rate greater than $300 \%$, according to [12] scale. In other words, regeneration density is three

Table 1. Estimated area of the main mangrove lots of the eastern coast of Madagascar.

\begin{tabular}{cccc}
\hline $\begin{array}{c}\text { Administrative } \\
\text { Region }\end{array}$ & Main sites & Area (ha) & $\begin{array}{c}\text { \% of all Eastern mangroves of } \\
\text { Madagascar }\end{array}$ \\
\hline Diana & Irodo & 1160 & 27.23 \\
& Ambodivahibe & 600 & 14.08 \\
& Rigny & 2071 & 48.62 \\
\hline Analanjirôfo & Mante Marie & 173 & 4.06 \\
& Mananara Nord & 100 & 2.30 \\
& Tampolo & $<0.5$ & 2.35 \\
Atsinanana & Foulpointe & $<2$ & $<0.01$ \\
\hline AtsimoAtsinanana & Farafangana & $<50$ & $<0.05$ \\
Anosy & Fort Dauphin & $<50$ & $<1.17$ \\
\hline
\end{tabular}

Table 2. Presence (x) of mangrove trees at the 5 sites surveyed.

\begin{tabular}{cccccc}
\hline Mangrove tree species & Rigny & $\begin{array}{c}\text { Mananara } \\
\text { Nord }\end{array}$ & Manompana & $\begin{array}{c}\text { Sainte } \\
\text { Marie }\end{array}$ & Foulpointe \\
\hline Rhizophora mucronata & $\mathrm{X}$ & $\mathrm{X}$ & $\mathrm{X}$ & $\mathrm{X}$ & $\mathrm{X}$ \\
Ceriops tagal & $\mathrm{X}$ & $\mathrm{X}$ & & $\mathrm{X}$ & \\
Bruguiera gymnorrhiza & $\mathrm{X}$ & $\mathrm{X}$ & $\mathrm{X}$ & $\mathrm{X}$ & $\mathrm{X}$ \\
Avicennia marina & $\mathrm{X}$ & $\mathrm{X}$ & $\mathrm{X}$ & $\mathrm{X}$ & $\mathrm{X}$ \\
Xylocarpus granatum & $\mathrm{X}$ & $\mathrm{X}$ & $\mathrm{X}$ & $\mathrm{X}$ & \\
Sonneratia alba & $\mathrm{X}$ & $\mathrm{X}$ & $\mathrm{X}$ & $\mathrm{X}$ & $\mathrm{X}$ \\
Lumnitzera racemosa & & $\mathrm{X}$ & $\mathrm{X}$ & $\mathrm{X}$ & $\mathrm{X}$ \\
Heritiera littoralis & & $\mathrm{X}$ & $\mathrm{X}$ & $\mathrm{X}$ & \\
\hline
\end{tabular}


to ten times higher than that of mature seed trees. However, the rates vary according to the sites studied, according to the type of mangrove and following a North-South gradient (Table 3). Indeed, the regeneration rate is low to medium $(<100 \%$ to $<300 \%)$ in the coastal mangroves of Mahela (Manompana); it is high, up to more than $500 \%$ in bays and lagoons as those of Rigny, Ampobe and Analapenja (Manompana), Forbans, Ikoa and Ampanihy (Sainte Marie), where the strength of sea waves is moderate, and the silting process more effective [5].

\subsection{Variable Vertical and Horizontal Structures along a South-North Gradient}

Respectively, the height and the basal area of the trees range between $1-12 \mathrm{~m}$ and $2.5-42 \mathrm{~m}^{2} \cdot \mathrm{ha}^{-1}$, depending on the site and, generally, according to a South-North gradient (Table 4).

\subsection{Potentially Significant Aboveground Biomass and Carbon Stock}

The aboveground biomass perfacies can go up to $47 \mathrm{t} \cdot \mathrm{ha}^{-1}$, or even more, at the level of the large homogeneous mangrove of Mananara and Rigny $\left(>70 \mathrm{t}^{\mathrm{h}} \mathrm{h}^{-1}\right)$, whereas this one does not exceed $10-20 \mathrm{t} \cdot \mathrm{ha}^{-1}$ in the sporadic mangroves of Foulpointe and Manompana. The carbon sequestration capacity at the level of the aboveground biomass is estimated at more than $5-20 \mathrm{t} \cdot \mathrm{ha}^{-1}$, along a

Table 3. Regeneration rate at the five sites surveyed.

\begin{tabular}{|c|c|c|c|}
\hline \multirow{2}{*}{ Sites } & \multicolumn{2}{|c|}{ Mangrove } & \multirow{2}{*}{ Regenerated species in order of dominance } \\
\hline & Littoral & Lagoon/bay & \\
\hline Rigny & $<100 \%$ & $>300 \%$ & Rhizophora m., Avicennia m. \\
\hline Bemanevika & & $>720 \%$ & Rhizophora m., Avicennia m. \\
\hline Ampanohara & $<100 \%$ & & Avicennia m. \\
\hline Antsaharavo & & $>400 \%$ & Rhizophora m., Avicennia m. \\
\hline Antsabemoko & & $>350 \%$ & Rhizophora m., Avicennia m., Ceriops t. \\
\hline Ampasira & & $>170 \%$ & Rhizophora m., Avicennia m., Ceriops $t$. \\
\hline Abigodra & & $>1000 \%$ & Rhizophra m., Bruguiera g., Ceriops t. \\
\hline Mananara Nord & & $>200 \%$ & Bruguiea g., Avicenia m., Rhizophora m. \\
\hline Manompana & $<300 \%$ & $>500 \%$ & Sonneratia a., Bruguiera g., Rhizophora m. \\
\hline Apombe & & $>75 \%$ & Bruguiera g., Rhizophora m. \\
\hline Analapenja & & $>900 \%$ & Sonneratia a., Avicennia m. \\
\hline Mahela & $<300 \%$ & & Sonneratia a., Bruguiera g. \\
\hline Sainte Marie & $<100 \%$ & $>300 \%$ & Rhizophora m., Bruguiera g., Ceriops $t$. \\
\hline Ampanihy & & $>500 \%$ & Rhizophora m., Ceriops t., Avicennia m. \\
\hline ForbansIkoa & & $>300 \%$ & Rhizophora m., Bruguiera g., Ceriops $t$. \\
\hline Marorano & & $<100 \%$ & Rhizophora m., Bruguiera g. \\
\hline Ambodiforaha & & $>300 \%$ & Rhizophora m., Bruguiera g. \\
\hline Saint Joseph & & $>300 \%$ & Rhizophora m., Lumnitzera $r$. \\
\hline La Pointe & $<100 \%$ & & Sonneratia a., Rhizophora m., Avicennia m. \\
\hline Tampolo & $<100 \%$ & & Ceriops $t$. \\
\hline Foulpointe & & $>900 \%$ & Avicennia m., Sonneratia a., Bruguiera g. \\
\hline
\end{tabular}


Table 4. Medium value of the main dendrometric parameters of mature trees.

\begin{tabular}{cccccc}
\hline Mangrove sites & $\begin{array}{c}\text { Height } \\
(\mathrm{m})\end{array}$ & $\begin{array}{c}\text { Density } \\
(\mathrm{mature} \text { tree } \\
\left.\mathrm{ha}^{-1}\right)\end{array}$ & $\begin{array}{c}\text { Diameter at } \\
\text { breast height } \\
(\mathrm{cm})\end{array}$ & $\begin{array}{c}\text { Basal area } \\
\left(\mathrm{m}^{2} \cdot \mathrm{ha}^{-1}\right)\end{array}$ & $\begin{array}{c}\text { Aboveground } \\
\text { biomass } \\
\left(\mathrm{t} \cdot \mathrm{ha}^{-1}\right)\end{array}$ \\
\hline Rigny & $3.5-12$ & $1000-7960$ & $3.8-22$ & $11-42$ & $>70$ \\
Mananara Nord & $3.6-8$ & $1600-3400$ & $3-18$ & $8-32$ & $>45$ \\
Manompana & $3-6$ & $1000-4000$ & $4-19.1$ & $6-34$ & $>40$ \\
Sainte Marie & $2.7-8$ & $1500-5400$ & $3-17$ & $5.1-22$ & $>46$ \\
Tampolo & $1-1.3$ & $<150$ & $1.5-4$ & $2.5-8$ & $<10$ \\
Foulpointe & $1.3-5$ & $300-3000$ & $3-14$ & $3.5-15$ & $<20$ \\
\hline
\end{tabular}

South-North gradient, equivalent to a minimum sequestration potential of 21,300 to $85,200 \mathrm{t}$ for the whole Eastern coast (Table 5).

\subsection{Still Low Pressures}

Despite the ecological potential and low annual clearing rates observed for some sites (Sainte Marie: $0.47 \%$, Foulpointe: $0.15 \%$, Rigny: $0.006 \%$, Mananara: $<0.47 \%$ ), this ecosystem is subject to anthropogenic pressures linked to urbanization (Sainte Marie, Foulpointe), timber harvesting (all sites) and the irrational exploitation of fishery resources (Sainte Marie, Manompana) (Table 6).

\section{Discussions}

Compared with the mangroves of the West Malagasy coast where the tidal range can reach $4.75 \mathrm{~m}$ [15], those of the East are subject to a low tidal range of less than $1 \mathrm{~m}$ [8]. Also, the weak hydrodynamic sedimentation process, as well as the strong exposure to coastal waves due to its straight shape and its position perpendicular to the wave forces, are not favorable factors for the installation of mangroves; hence the scattered and localized nature of the latter. The mangrove sites in the East are more concentrated in the few areas with muddy accumulation and little exposed to the sea currents. [16] describes them as small mangroves because of their small surface area; a qualification re used by several authors such as [1]. It should also be noted that other small mangrove sites, other than the five surveyed in this study, are reported by [17], in Diego Suarez bay, at Nosy Komba, at Loky Manambato and at Mangerina, respectively in Diana and Sava Regions (North of Madagascar). According to [18], the protected area of Loky Manambato (Sava Region) has, at its three sites of Ampasimbania, Antafianivony and Loky, a few lots of dense mangrove from 200 to 1220 individuals.ha ${ }^{-1}$, with a basal area of 2.1 to $32.8 \mathrm{~m}^{2} \cdot \mathrm{ha}^{-1}$ and a biovolume of 0.7 to 34.5 $\mathrm{m}^{3} \cdot \mathrm{ha}^{-1}$.

All the mangroves of the East and West of Madagascar belong to the Indo-Pacific region [19] and have the same floristic diversity. 8 species out of the 9 characteristics of the Eastern African coastscited by [20] and [21] can be found in the East of Madagascar; only the Avicennia officinalis species is absent. It 
Table 5. Production of aboveground biomass and carbon stock estimated per site.

\begin{tabular}{cccc}
\hline \multirow{2}{*}{ Mangrove sites } & $\begin{array}{c}\text { Aboveground } \\
\text { biomass }\left(\mathrm{t} \cdot \mathrm{ha}^{-1}\right)\end{array}$ & \multicolumn{2}{c}{ Carbon stock } \\
\cline { 3 - 4 } & $>70$ & $\left(\mathrm{t} \cdot \mathrm{ha}^{-1}\right)$ & total site ( $)$ \\
\hline Rigny (2071 ha) & $>45$ & $>35$ & $>72,485$ \\
Mananara Nord (100 ha) & $>40$ & $>22.5$ & $>2250$ \\
Manompana (98 ha) & $>46$ & $>23$ & $>1960$ \\
Sainte Marie (173 ha) & $<10$ & $<5$ & $>3979$ \\
Tampolo (<0.5 ha) & $<20$ & $<10$ & $<2.5$ \\
Foulpointe (<2 ha) & & & $<20$ \\
Total mangroves of the East & $10-40$ & $5-20$ & $21,300-85,200$ \\
of Madagascar & & & \\
\hline
\end{tabular}

Table 6. Percentage distribution of the 8 main uses of mangrove resources.

\begin{tabular}{|c|c|c|c|c|c|c|c|c|}
\hline \multirow[b]{2}{*}{$\begin{array}{l}\text { Mangrove } \\
\text { sites }\end{array}$} & \multicolumn{8}{|c|}{ The 8 main uses of mangrove resources } \\
\hline & 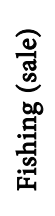 & 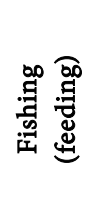 & 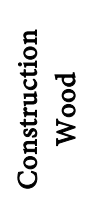 & $\begin{array}{l}0 \\
8 \\
3 \\
3 \\
50 \\
\stackrel{5}{0}\end{array}$ & 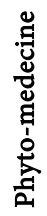 & 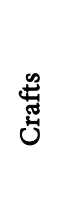 & 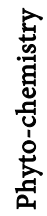 & 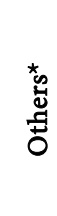 \\
\hline Rigny & 20 & 0 & 0 & 0 & 0 & 0 & 0 & 80 \\
\hline Mananara N. & 20 & 20 & 10 & 0 & 0 & 0 & 0 & 50 \\
\hline Manompana & 18 & 25 & 20 & 30 & 2 & 0 & 0 & 5 \\
\hline Sainte Marie & 28 & 36 & 3 & 0.5 & 8 & 0.5 & 4 & 20 \\
\hline Tampolo & 0 & 20 & 0 & 0 & 0 & 0 & 0 & 80 \\
\hline Foulpointe & 30 & 0.2 & 20 & 2 & 0 & 0 & 0 & 47.8 \\
\hline
\end{tabular}

*: human dwelling, conservation, tourism, etc.

should be noted that the presence of the latter in Madagascar has been reported by [22].

The presence of Heritiera littoralis Ait (Sterculiaceae) and Lumnitzera racemosa Willd (Combretaceae) on the Eastern coast of Madagascar shows that the following ecological conditions of installation of those two species also exist in the East: a site located in back mangrove where water is less salty and banks of fresh water subject to tides. It means it would be possible to find micro-habitats similar to those recorded in the West of the big island, in the East of Madagascar.

The abundance of natural regenerations in a mangrove ecosystem is common, if one refers to the study conducted by [11] in the Mangoky Delta, in southwestern Madagascar where mangrove seedlings account for $89 \%$ of all trees, as well as to works carried out by [23] in Vietnam, [24] and [25] in the Tsiribihina Delta-SW Madagascar, and [26] in Besalampy-NW Madagascar, all of which confirm the spatial advance of mangroves as per the fattening mechanism described 
by [27] and [28]. The mangroves of Eastern Madagascar are no exception, given the importance of seed trees on the one hand ( $>1000$ individual $s \cdot h^{-1}$, Table 4 ), and the abundance of seedlings on the other hand (more than 3 times the number of seed trees, Table 5). The regenerations are particularly abundant in bays and lagoons less exposed to wave as Rigny, Analapenja (Manompana), Forbans Ikoa, Ambodiforaha and Ampanihy (Sainte Marie).

Referring respectively to the trees of the Mangoky Delta (southwestern Madagascar), Tsiribihina and Sahamalaza (West Madagascar) where the total height of the trees is between 3.66 and $7.14 \mathrm{~m}$ [11] and 2 to $12 \mathrm{~m}$ [29], those of the East are lower $(2.47$ to $6.88 \mathrm{~m}) .50 .40 \%$ and $1 \%$ of the delta trees measure respectively $2-4 \mathrm{~m}, 4-6 \mathrm{~m}$ and more than $12 \mathrm{~m}$ [11] compared to 63.25 and $0.6 \%$ for all 5 sites studied in the East. Consisting mainly of isolated Sonneratia alba trees at seafront, of Rhizophora mucronata individuals in quiet places undisturbed by waves and human actions, or Avicennia marina trees more than 50 years in back mangrove, big trees over $12 \mathrm{~m}$ with a diameter greater than $20 \mathrm{~cm}$ are rare on the Eastern coast. If average diameters range from 2.88 and $14.83 \mathrm{~cm}$ in the East, they are respectively lesser than $5 \mathrm{~cm}$ and between 5 and $15 \mathrm{~cm}$ for $40 \%$ and nearly the third the Mangoky Delta trees [11]. Compared to that of the delta ( 9.69 to $43.86 \mathrm{~m}^{2} \cdot \mathrm{ha}^{-1}$ depending on the facies), the average basal area of the East is lower, ranging from 6.35 to $24.33 \mathrm{~m}^{2} \cdot \mathrm{ha}^{-1}$. With values ranging from 2.1 to $32.8 \mathrm{~m}^{2} \cdot \mathrm{ha}^{-1}$ [18], that of the protected areas as Loky Manambato, do however have higher maximum mean basal area.

In terms of aboveground biomass, those of Sainte Marie, Manompana, Mananara Nord and Rigny are comparable with the figures obtained by [11] in the Mangoky Delta where 20 to $180 \mathrm{t} \cdot \mathrm{ha}^{-1}$ of leaves, branches, boles, flowers and fruits were harvested. However, the effectiveness of the allometric relations between the diameter at breast height of trees $x$ and the aboveground biomass $y$, with $y=0.248 x^{2373}\left(\mathrm{R}^{2}=0.959\right)$ for Rhizophora mucronata, and $y=0.134 x^{2399}$ $\left(\mathrm{R}^{2}=0.915\right)$ for Avicennia marina [11], still needs verifications for the case of the Malagasy East.

The amount of carbon sequestered at the level of the aboveground part of the mangroves of East Madagascar is not negligible if one refers to ecosystem services that derive from it. Indeed, with a hypothetical price of 9 USD the ton ${ }^{1}$, an annual carbon income of around 191,700 to 766,800 USD could be generated, just at the aboveground part of this ecosystem. It should be noted that according to [30], 35\% of the carbon is in the aboveground part of a mangrove, while $65 \%$ are stored in soils and roots. In other words, the carbon contained in the climax of the eastern mangrove could also be sold on the carbon market. With such a financial opportunity, we can fund the preservation activities that should be done at the level of each mangrove lot, support the stakeholders in charge of the management of the various lots, by granting them control and monitoring tools

${ }^{1}$ The rate of one ton of carbon was around 8 Euros on the European market in November 2015, Source: https://www.novethic.fr/empreinte-terre/climat 
essential to their activities, and strengthening their socio-organizational and technical capacities.

In addition to the possible spatial advances related to the fattening mechanism and the abundance of regeneration [11] [23]-[28], the small annual spatial losses recorded at the main mangrove sites on the east coast of Madagascar are also linked to the availability of woody plants such as fuel and construction timber on the dry land. The woodlands of Eucalyptus sp. and Acacia sp., just as the formations with Melaleuca quinquenervia are not only more accessible, but their energy quality are more appreciated by the local residents. Such is the case of Rigny where its mangrove lots are spared from cutting thanks to the existence of continental formations in the area [10]. For the case of the Tsiribihina (west coast of Madagascar), the greater the distance between the village and the Mangrove sites, the less villagers stock up on mangrove wood [29]. The same is true for the case of Sainte Marie where residents prefer to go for the Eucalyptus and Melaleuca trees, rather than harvesting mangrove trees for energy and/or construction purposes [2]. The spatial decline rates of the Sainte Marie, Manompana, Foulpointe, Tampolo and Rigny mangroves thus remain below the annual national rates of $1.34 \%$ [31] and $1.06 \%$ [1]. They are also still low, if we refer to the annual spatial loss of $1.75 \%$ advanced by [32] over the past two decades.

\section{Conclusion}

The mangroves of Madagascar eastern coast have a certain number of ecological potentials, especially at homogenous mangrove sites such as Irodo, Ambodivahibe, Rigny and Sainte Marie, where the horizontal and vertical structures of the trees are comparable to those of the Malagasy West. They are dynamic ecosystems subject to generally weak but more significant pressures in urbanized areas such as Sainte Marie and Foulpointe. Their natural regeneration capacity is an asset for their recovery, as is their capacity for carbon sequestration, a promising aspect in terms of mangrove economic valuation.

\section{Conflicts of Interest}

The authors declare no conflicts of interest regarding the publication of this paper.

\section{References}

[1] Jones, T.G., Glass, L., Gandhi, S., Ravaoarinorotsihoarana, L., Carro, A., Benson, L., Rakoto Ratsimba, H., Giri, C., Randriamanatena, D. and Cripps, G. (2016) Madagascar's Mangroves: Quantifying Nation-Wide and Ecosystem Specific Dynamics, and Detailed Contemporary Mapping of Distinct Ecosystems. Remote Senings, 8 , 106.

[2] Rasoamanarivo, R.M.M. (2017) La mangrove de Sainte Marie, un écosystème aux enjeux multiples (The Mangrove of Sainte Marie, an Ecosystem with Multiple Challenges). Mémoire de Master II. Mention Géographie, Université d'Antananarivo, Antananarivo, $60 \mathrm{p}$.

[3] Mumby, P.J., Edwards, A.J., Arias-Gonzalez, J.E., Lindeman, K.C., Blackwell, P.G., 
Gall, A., Gorczynska, M.I., Harborne, A.R., Pescod, C.L., Renken, H., Wabnitz, C.C. and Lewellyn, G. (2004) Mangroves Enhance the Biomass of Coral Reef Fish Communities in the Caribbean. Nature, 427, 533-536.

https://doi.org/10.1038/nature02286

[4] Rakotomavo, A., Mandimbinirina, D.S. and Roger, E. (2018) Development Prospects of the Mangrove Relic of Foulpointe-East Madagascar. Journal of Environmental Protection, 9, 859-869. https://doi.org/10.4236/jep.2018.98053

[5] Rakotomavo, A., Rasoamanarivo, R.M.M. and Razanajaza, P. (2018) Impact of Urban Anthropogenic Pressures on the Mangrove Forest of Sainte Marie (East Madagascar). Open Journal of Forestry, 8, 380-392.

https://doi.org/10.4236/ojf.2018.83024

[6] WWF (2007) Etat des lieux des Mangroves face au changement climatique à Madagascar (State of the Mangroves in the Face of Climate Change in Madagascar). $30 \mathrm{p}$.

[7] Jeannoda, V. and Roger, E. (2008) Honko, introduction générale (Honko, Genearal Introduction). Honko 1. Département de Biologie et Ecologie Végétales, Faculté des Sciences d'Antananarivo, $252 \mathrm{p}$.

[8] Caveriviere, A., et al. (2008) Les crevettes côtières de Madagascar: Biologie, exploitation, gestion (Madagascar's Coastalshrimp: Biology, Exploitation and Management). Institut de Recherche pour le Développement, Marseille, 361 p. https://doi.org/10.4000/books.irdeditions.10430

[9] Andriamalala, C.A.J. (2007) Etude écologique pour la gestion des mangroves à Madagascar-Comparaison d'une mangrove de littorale et d'estuaire à l'aide de la télédétection (Ecologicalstudy for Mangrove Management in MadagascarComparison of Littoral and Estuary Mangroves usingremotesensing). Thèse de doctorat, Université de Basel, Basel, 268 p.

[10] Andrianoelisoa, R.H. (2017) Etude des valorisations durables du potentiel en biomasse de la mangrove de la Baie de Rigny du District d'Antsiranana II (Sustainable Valuations Study of the Rigny Bay Mangrove BiomasspotentialAntsiranana II District). Mémoire de Master II. Mention Géographie, Université d'Antananarivo, $63 \mathrm{p}$.

[11] Rakotomavo, A. (2010) Etat des lieux et dynamique de la mangrove du Delta de Mangoky, Sud-Ouest de Madagascar (State of the Scene and Dynamics of the Mangroves of the Mangoky Delta, South West Madagascar). Thèse de doctorat ès Sciences Agronomiques, Université d'Antananarivo, Antananarivo, $151 \mathrm{p}$.

[12] Rothe, P.L. (1964) Régénération naturelle en forêt tropicale: Le Dipterocarpus dyeri (Dau) sur le versant cambodgien du golfe du Siam (Natural Regeneration in the Rainforest: The Dipterocarpus dyeri (Dau) on the Cambodianside of the Siam Gulf). Bois et Forêt des Tropiques, 8, 386-397.

[13] Randrianarison, A. (2009) Dynamique des écosystèmes forestiers en contact avec les savanes dans le corridor forestier de Fianarantsoa (Sahabe-Ambohimahamasina) à Madagascar (Dynamics of Forest Ecosystems in Contact with Savannas in the Forest Corridor of Fianarantsoa (Sahabe-Ambohimahamasina), Madagascar). Mémoire de Diplôme d'Etudes Approfondies en Biologie et Ecologie Végétales, Université d'Antananarivo Madagascar, Antananarivo, $60 \mathrm{p}$.

[14] Dupouey, J.L. and Pignard, G. (2001) Quelques problèmes posés par l'évaluation des flux de carbone forestier au niveau national (Some Issues Related to the Assessment of Forest Carbon Flow Sat the National Level). Revue Forestière Française, 53, 294-300.

[15] Green-OI (1998) Mission pilote d'évaluation de l'érosion côtière et des risques sur 
les aménagements de la ville de Morondava Madagascar (Pilot Mission to Assess Coastal Erosion and Risk on Development of Morondava Town-Madagascar). Rapport, $99 \mathrm{p}$.

[16] Lebigre, J.M. (1984) Problématiques de recherche sur les marais maritimes de Madagascar en vue de leur protection et leur aménagement (Research Issues for Protection and Development of Madagascar's Marine Marshes). Revue de Géographie, 44, 45-74.

[17] Roger, E. (2001) L'aquaculture de crevette à Madagascar (Climatologie-Végétation et Flore-Ecologie) (Shrimp Aquaculture in Madagascar (Climatology, Vegetation \& Flora, Ecology)), Rapport Provisoire, 20 p.

[18] Fanamby (2014) Nouvelle Aire Protégée Loky Manambato, paysage harmonieux protégé, plan d'aménagement 2014-2018 (New Protected Area Loky Manambato, Harmonious Land Scape Protected, Development Plan 2014-2018). MEEF, Global Conservation Fund, GIE Sahanala, AnkaoProperties S.A., Florlbis, PNUD-GEFMRPA.

[19] Macnae, W. (1963) Mangrove Swamps in South Africa. Journal of Ecology, 51, 1-25. https://doi.org/10.2307/2257502

[20] SECA (1986) Les mangroves d'Afrique et de Madagascar, protection et mise en valeur (The Mangroves of Africa and Madagascar, Protection and Development). Rapport du Centre d'Etudes de l'Environnement, Université de Leyde, Leyde, 24 p.

[21] PNUE (2003) Mangroves of East Africa, PNUE-Programme pour les mers régionales, UNEP-WCMC.

[22] Taylor, M., Ravilious, C. and Green, E.P. (2003) Mangroves of East Africa. UNEPWCMC Biodiversity Series No.13. https://www.unep-wcmc.org/

[23] Hong, P.N. and San, H.T. (1993) Mangroves of Vietnam. IUCN Wetlands Programme, Gland, Switzerland, $173 \mathrm{p}$.

[24] Andriamasinoro, S.M. (1993) Mobilité: Réponses des sociétés paysannes face à l'instabilité des conditions naturelles d'un milieu deltaïque. Exemples de quelques villages du delta de la Tsiribihina, centre ouest de Madagascar (Mobility: Responses of Farmersocieties to the Instability of the Natural Conditions of a Delta Environment. Examples of Some Villages in the Tsiribihina Delta, West Central Madagascar). Mémoire de l'Ecole Normale Supérieure de l'Université d'Antananarivo, Antananarivo, $92 \mathrm{p}$.

[25] Ratsimba, L.H. (1993) Stratégies paysannes de l'utilisation d'un milieu deltaïque: Exemple de Kaday, delta de la Tsiribihina-Centre Ouest de Madagascar (Farmerstrategies for the Use of a Delta Environment: Example of Kaday, Tsiribihina Delta-West Central Madagascar). Mémoire pour l'obtention du CAPEN, Ecole Normale Supérieure de l'Université d'Antananarivo, Antananarivo, $115 \mathrm{p}$.

[26] Ioniarilala, R. (2000) Les impacts écologiques de la crevetticulture industrielle sur l'écosystème mangrove, cas de la région de Besalampy (The Ecological Impacts of Industrial Shrimp on the Mangrove Ecosystem, Case of the Besalampy Region). Mémoire d'ingéniorat. Ecole Supérieure des Sciences Agronomiques de l'Université d'Antananarivo, Antananarivo, Madagascar, 90 p.

[27] Lebigre, J.M. (1988) Le Marais maritime de la Tsiribihina à Madagascar (The Tsiribihina Marine Marsh in Madagascar). Bois et Forêts des Tropiques, 215, 37-60.

[28] Rakotomavo, A. and Fromard, F. (2010) Dynamics of Mangrove Forests in the Mangoky River Delta, Madagascar, under the Influence of Natural and Human Factors. Forest Ecology and Management, 259, 1161-1169. 
https://doi.org/10.1016/j.foreco.2010.01.002

[29] Razakanirina, H. (2016) Les Mangroves de Madagascar: Utilisation des Ressources en bois, caractéristiques anatomiques du bois et vulnérabilité écologique par rapport au changement climatique (Cas des mangroves du delta de Tsiribihina et de la Réserve de Biosphère de Sahamalaza) (The Mangroves of Madagascar: Use of Wood Resources, Anatomical Characteristics of Wood and Ecological Vulnerability in Relation to Climate Change (Case of the Tsiribihina Delta Mangroves and the Sahamalaza Biosphere Reserve)). Thèse de Doctorat en Sciences de la vie et de l'Environnement-Sciences du Végétal, Université d'Antananarivo, Antananarivo, $177 \mathrm{p}$.

[30] PNUE (2013) Mangroves d'Afrique Centrale: Des puits de carbone aux multiples atouts (Central African Mangroves: Carbon Wells with Multiple Strengths). Une évaluation pour la REDD+, Programme ONU REDD, IRP, PNUD, PNUE.

[31] Giri, C. and Muhlhausen, J. (2008) Mangrove Forest Distributions and Dynamics in Madagascar (1975-2005). Sensors, 8, 2104-2117.

[32] Valiela, I., Bowen, J.L. and York, J.K. (2001) Mangrove Forests: One of the World's Threatened Major Tropical Environments. Bioscience, 51, 807-815. 